\title{
Potential role of high-mobility group box 1 protein in the pathogenesis of influenza $\mathrm{H} 5 \mathrm{~N} 1$ virus infection
}

\author{
X. Q. HOU ${ }^{1,2}$, J. L. QIN ${ }^{1}$, X. X. ZHENG ${ }^{1}$, L. WANG ${ }^{2}$, S. T. YANG ${ }^{1}$, Y. W. GAO ${ }^{1 *}$, X. Z. H. XIA ${ }^{1 *}$
}

\begin{abstract}
${ }^{1}$ Veterinary Institute, Academy of Military Medical Sciences, 666 Liuyingxi Road of Jingyue Development Zone, Changchun, Jilin province, 130122, P. R. China; ${ }^{2}$ Beijing Institute of Biotechnology, 20 Dongdajie Street, Fengtai District, Beijing, 100071, P. R. China.
\end{abstract}

Received May 9, 2013; accepted February 25, 2014

\begin{abstract}
Summary. - During influenza A virus (IAV) (H5N1) infection, the levels of inflammatory cytokines are markedly elevated in the lungs of infected hosts. One of them, high-mobility group box 1 protein (HMGB1) functions in regulation of cellular transcription and activation of proinflammatory responses, but little is known about its role in viral infection. In this study, we attempted to address this question. Using an IAV (H5N1) - mouse model, lung tissues were analyzed for virus titer, expression of HMGB1 and other inflammatory cytokines and histopathological changes. Moreover, the effect of administration of HMGB1-specific antibody to the infected mice on these parameters was investigated. The results showed that the HMGB1 expression was induced on days 3-7 post infection (p.i.) and primarily localized to epithelial cells of alveoli and bronchioles. The HMGB1specific antibody reduced the levels of inflammatory cytokines and chemokines and the survival rate, but did not influence the virus titer. Summing up, these data suggest that HMGB1 contributes to the pathogenesis of IAV (H5N1) infection in mice by inducing extensive inflammatory responses and severe pneumonia.
\end{abstract}

Keywords: HMGB1; influenza A virus (H5N1); pathogenesis

\section{Introduction}

Previous studies have shown that excessive cytokine responses with recruitment of inflammatory immune cells to the lung were key contributors to the high morbidity and significant mortality of the 1918 influenza and IAV (H5N1) infection (de Jong et al., 2006; Kobasa et al., 2007). In support of this statement, CCR2-deficient mice were protected from early pathological manifestations despite higher pulmonary titers of the influenza virus A/PR/8/34 (H1N1) strain (Dawson et al., 2000). Tumor necrosis factor receptor 1 (TNFR-1)deficient mice exhibited significantly reduced morbidity following challenge with IAV (H5N1) (Szretter et al., 2007), and

“Corresponding authors. E-mail: gywtext@yahoo.com.cn, xia_xzh@ yahoo.com.cn; phone: +86-431-86985516, +86-431-86985517.

Abbreviations: HMGB1 = high-mobility group box 1; IAV = influenza A virus; IFN = interferon; IL- $1 \beta=$ interleukin $1 \beta$; IL- 6 = interleukin 6 ; IP-10 = IFN-inducible protein 10; p.i. = post infection; RANTES $=$ regulated upon activation, normal T-cell expressed and secreted protein; TNF- $\alpha=$ tumor necrosis factor $\alpha$ other cytokines or chemokines have also been investigated (Schmitz et al., 2005; Deng et al., 2008). Thus, at least some of the elevated proinflammatory cytokines may contribute to the pathogenesis of IAV

HMGB1 is a $25 \mathrm{KDa}$, nonhistone, nucleosomal protein (Bianchi et al., 2007). HMGB1 protein can be released passively by necrotic cells and/or actively by activated immune cells such as dendritic cells, monocytes and macrophages, into the extracellular milieu to function as a proinflammatory cytokine in response to injury, infection and inflammation (Andersson et al., 2000; Messmer et al., 2004; Yang et al., 2005). Evidence is accumulating for the involvement of HMGB1 during the course of viral infections. It was shown to be released from cells infected with a range of viruses, including dengue virus, hepatitis $\mathrm{C}$ virus, HSV-2 and HIV (Kamau et al., 2009; Barqasho et al., 2010; Jung et al., 2011); however, the involvement of HMGB1 in the IAV infection, and its contribution to the excessive inflammatory cytokine response associated with severe influenza cases, remains largely unknown. Increased levels of HMGB1 were detected in sera from patients with IAV infection and bacterial 
pneumonia, and in sera from IAV (H1N1) pdm09-infected children with severe pneumonia (Kosai et al., 2008; Ito et al., 2011). In a mouse model of severe influenza infection, elevated HMGB1 levels were observed in bronchoalveolar lavage fluids (Van et al., 2009).

In this study, the role of HMGB1 in IAV (H5N1)-infected mice was investigated. The results revealed that (1) the infection induces increased HMGB1 levels in the lungs, (2) the released HMGB1 contributes to extensive inflammatory responses and severity of pneumonia, and (3) the effect of HMGB1 can be blocked by a HMGB1-specific antibody.

\section{Materials and Methods}

Virus, cells and mice. A stock of influenza virus A/Chicken/ Harbin/01/2003(H5N1), further abbreviated as Harbin/01, was propagated in the allantoic cavity of 10-day-old embryonated chicken eggs at $37^{\circ} \mathrm{C}$ for $48 \mathrm{hr}$. The allantoic fluid was then harvested, aliquoted, and stored at $-70^{\circ} \mathrm{C}$. Infectious virus titer $\left(\mathrm{TCID}_{50} / \mathrm{ml}\right)$, based on CPE, was assayed in MDCK cells. The entire work with this virus was carried out in a BSL-3 biocontainment facility. SPF female BALB/c mice, 18-20 g body weight, were purchased from Beijing Experimental Animal Center (China). HMGB1-specific antibody was prepared in a rabbit immunized with Escherichia coli-expressed mouse HMGB1 protein.

Experiments on mice. SPF female BALB/c mice were lightly anesthetized with ether and inoculated intranasally with 100 $\mathrm{TCID}_{50}$ Harbin/01 virus in $50 \mu \mathrm{l}$. Control mice received UVinactivated virus or PBS. UV-inactivated virus, as validated by cell culture-based assay, had no effect on the hemagglutinin (HA) titer by HA assay in PBS. To further address the role of HMGB1 in virus-infected mice, virus-infected mice were injected intraperitoneally with HMGB1-specific antibody (200 $\mu \mathrm{g} /$ mouse) on days 1 and 4 p.i. Control infected mice received an equivalent volume of PBS alone. Mice were monitored daily for morbidity and mortality, and weights were measured daily throughout the infection. To monitor virus titers and levels of cytokines and chemokines in serum and lungs, the mice were euthanized and whole lungs and serum samples were collected daily until day 7 p.i. The samples were frozen and stored at $-70^{\circ} \mathrm{C}$ until assayed, while lung samples for histological and immunochemical analyses were fixed in buffered $10 \%$ formalin. For each time interval a group of 3 mice was used.

Real-time PCR for HMGB1 mRNA. For determination of mRNA levels of various cytokines, total RNA was prepared from frozen lung samples using TRIzol reagent (Invitrogen, USA) and RNeasy Mini kit (TaKaRa, China). cDNA was synthesized using oligo-dT primers and Superscript II reverse transcriptase (Invitrogen, USA), and amplified by real-time PCR using specific oligonucleotide primers (Table 1) and the ABI Prism 7,000 Sequence Detection System (Applied Biosystems, USA). HMGB1 mRNA titers were normalized using $\beta$-actin as a standard. Results were expressed as mean \pm SD values from at least 3 samples.

Western blot analysis of HMGB1 protein. Total protein extracts of lung tissues were prepared for western blot analysis in ice-cold lysis buffer $(150 \mathrm{mmol} / \mathrm{l} \mathrm{NaCl}, 1 \% \mathrm{NP} 40,0.5 \% \mathrm{Na}$ deoxycholate, $0.1 \%$ SDS and $50 \mathrm{mmol} / \mathrm{l} \mathrm{Tris-HCl,} \mathrm{pH}$ 8.0). Proteins of the lysates were then separated by SDS-PAGE and analyzed by Western blotting with HMGB1 antibody (Abcam, USA). The blots were developed with a Western Luminescent Kit (Vigorous Biotechnology, China) and bands visualized using an X-ray film.

ELISA of serum cytokines. Frozen sera were thawed on ice and clarified by centrifugation. Using ELISA kits, concentrations of HMGB1 (ADL Company, USA), IL-1 $\beta$, IL-6, TNF- $\alpha$, IP-10, and RANTES (R\&D Systems, USA) in serum were determined following the manufacturers' protocols. The detection limit was $2 \mathrm{pg} / \mathrm{ml}$ for HMGB1, $1.88 \mathrm{pg} / \mathrm{ml}$ for TNF- $\alpha, 1.6 \mathrm{pg} / \mathrm{ml}$ for IL-6, 2.31 pg/ml for IL-1 $\beta, 2.2 \mathrm{pg} / \mathrm{ml}$ for IP-10, $2 \mathrm{pg} / \mathrm{ml}$ for RANTES. Results were expressed as mean \pm SD values from at least 3 samples.

Infectious virus titration. Individual lungs were completely homogenized in $2 \mathrm{ml}$ cold PBS containing 100 units/ml penicillin and $100 \mu \mathrm{g} / \mathrm{ml}$ streptomycin. The serial dilutions of lung samples from $10^{-1}$ to $10^{-10}$ were added onto a monolayer of MDCK cells in 96-well culture plates for 2 to 3 days. CPE was examined by light microscopy and titers of individual viral samples were calculated by the Reed-Münch method (Pandiri et al., 2007).

Histopathology, immunochemical staining. Harvested lung tissues from each time point and each experimental group were fixed in $10 \%(\mathrm{v} / \mathrm{v})$ buffered neutral formalin, then processed for paraffin embedding and sectioning by routine methods. A part of slides were stained with hematoxylin and eosin for light microscopy. Other slides were stained with rabbit antibody to HMGB1.

Statistical analysis. Results were expressed as mean \pm SD values for each series of experiments. All analyses were performed by unpaired $t$ test using the Statistical Package for Social Sciences (SPSS) Version 13.0. Results were considered statistically significant at $P<0.05$.

\section{Results}

The virus infection induces HMGB1 expression in mouse lungs

Following viral infection, $\mathrm{HMGB} 1 \mathrm{mRNA}$ levels in mouse lung were slightly increased on day 3 and more markedly on day 4 , with the highest level being observed on day 5 p.i. (Fig. 1a). Compared with control mice given inactivated virus, the difference was statistically significant $(P<0.05)$. HMGB1 mRNA levels started to decrease on day 6 , but remained high. Western blot analysis showed that the infection resulted in a notable increase of HMGB1 expression by day 5 (Fig. 1c). Moreover, HMGB1 concentrations in the sera of infected mice were increased on day 3 , with highest titers on day 5 , by 
which time most mice exhibited severe disease (Fig. 1b). Immunohistochemical staining showed that bronchiolar epithelial cells, alveolar epithelial cells, and intercellular spaces contained high quantities of HMGB1 (Fig. 1d). These data show that IAV (H5N1) infection positively upregulated HMGB1 expression during the middle and late phases of infection.
Blocking of HMGB1 with specific antibodies reduces the inflammatory response, morbidity and mortality in virusinfected mice

The occurrence of a "cytokine storm" has been proposed to contribute to the increased severity of disease caused by

(a)
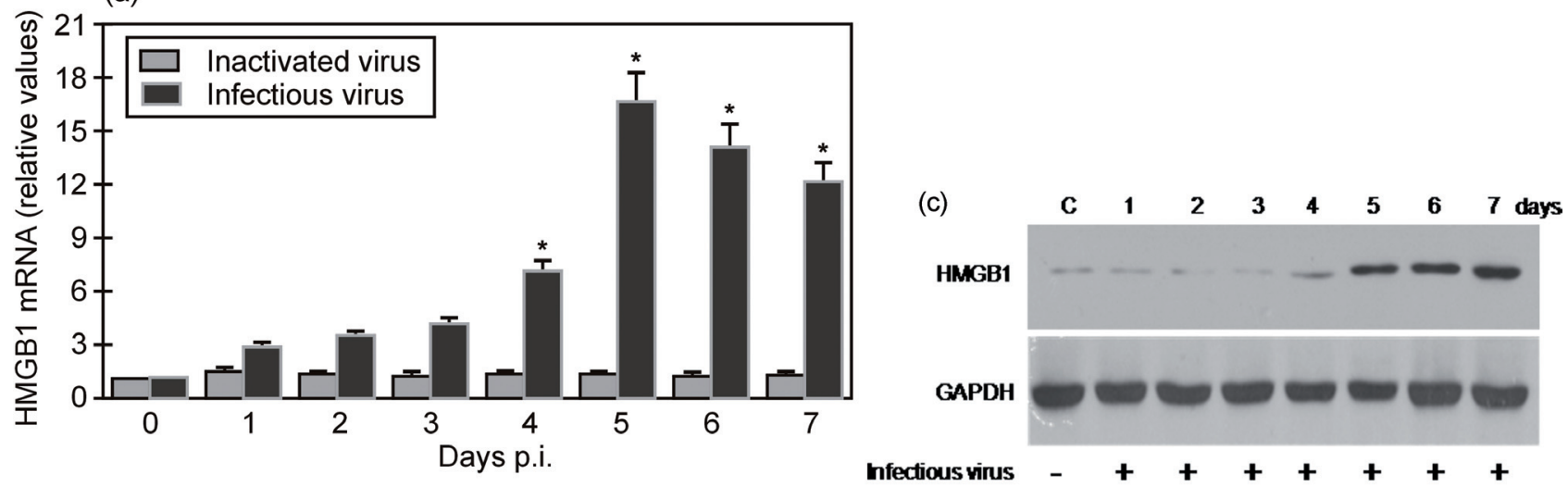

(b)
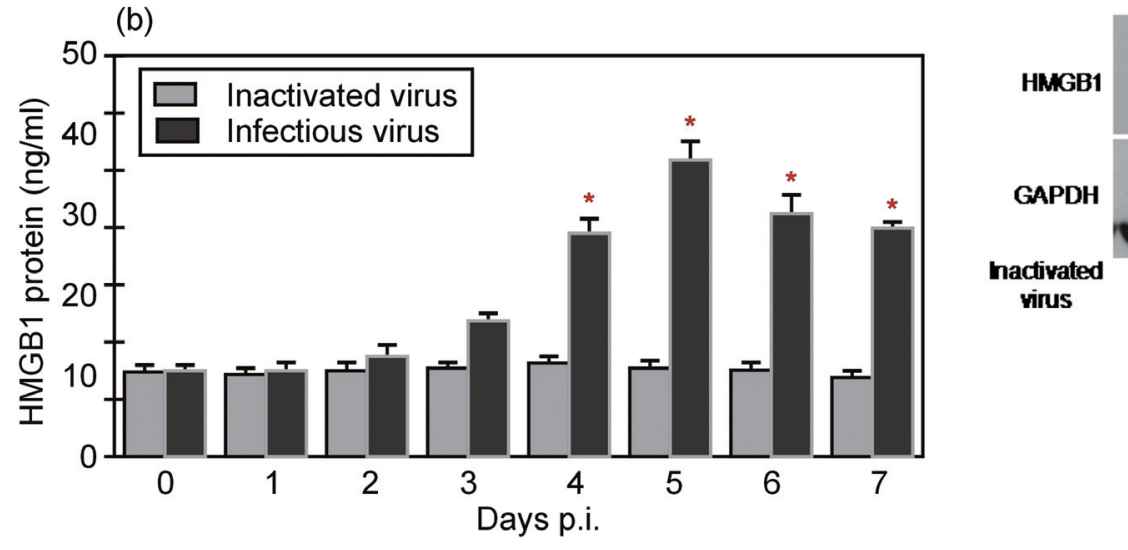

(d)
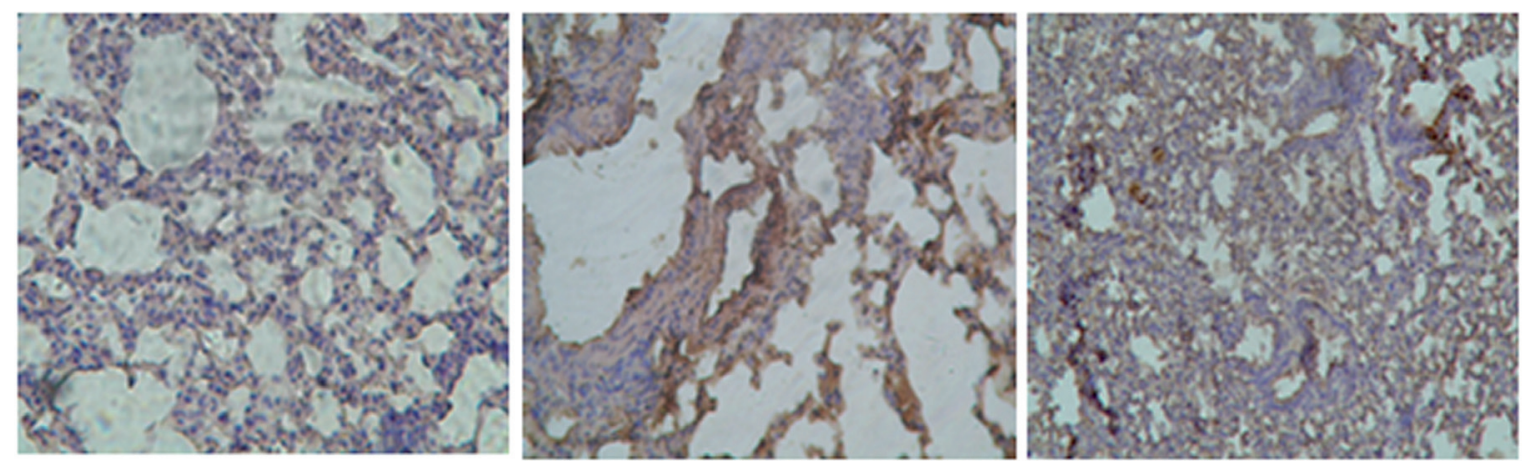

Fig. 1

The virus infection induces HMGB1 expression in mouse lungs

Expression of HMGB1 mRNA as detected by real-time RT-PCR (a), HMGB1 protein in serum as detected by ELISA (b), and HMGB1 level of lung tissues as detected by Western blot (c). HMGB1 protein detected in the lungs by immunochemical staining, magnification $25 \mathrm{x}$ (d). ${ }^{\star} P<0.05$. 
IAV (H5N1) (Chan et al., 2005; de Jong et al., 2006). To directly examine the contribution of HMGB1 during IAV (H5N1) infection, we blocked HMGB1 using HMGB1specific antibody to measure the levels of inflammatory cytokine (IL-1 $\beta$, IL-6, TNF- $\alpha$, IP-10, and RANTES), which are widely thought to be relevant to the pathogenesis of IAV (H5N1) in the mouse model. As shown in Fig. 2, the levels of IL- $1 \beta$, IL-6, TNF- $\alpha$, IP-10, and RANTES were significantly lower in mice treated with HMGB1-specific antibody at day 4 p.i. $(P<0.05)$.

(a)

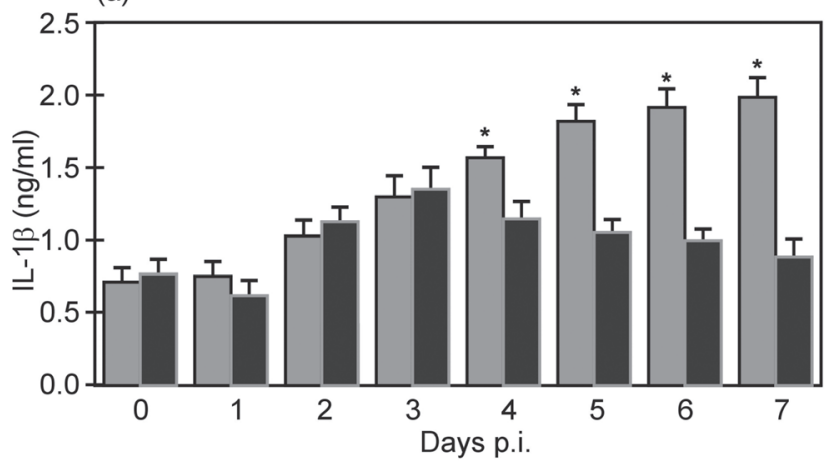

(c)

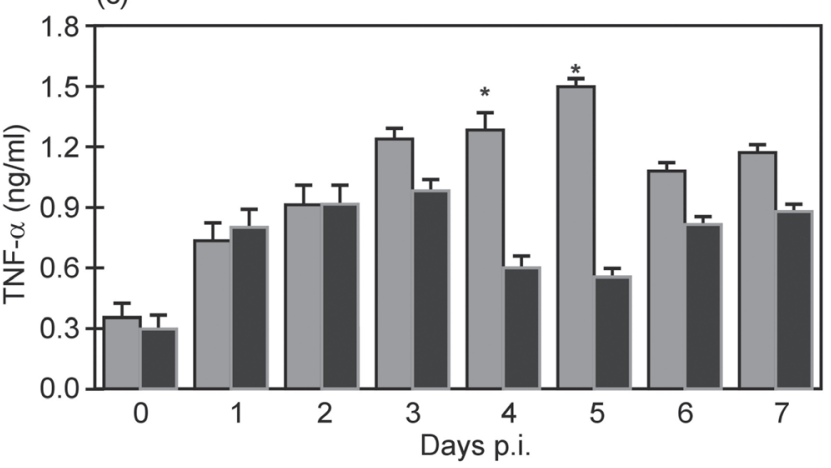

(e)

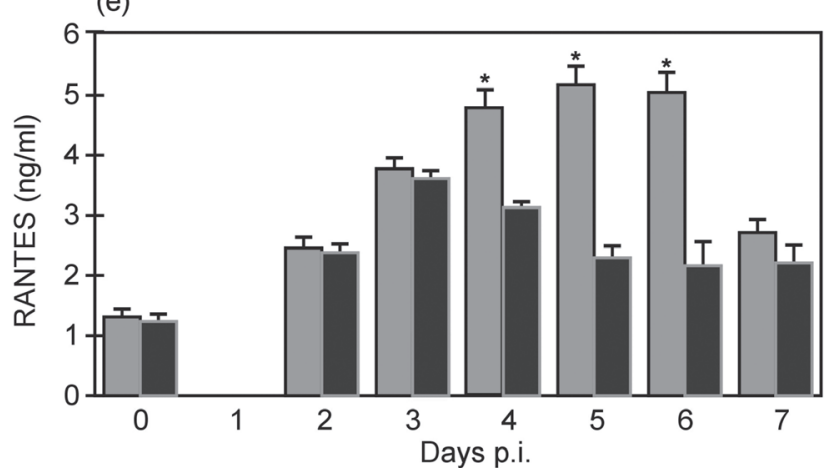

To determine how HMGB1 alters survival in IAV (H5N1)-infected mice, virus-infected mice were treated with HMGB1-specific antibody. Body weight and pulmonary viral load were measured at various times after infection. Body weight loss was significantly more apparent in infected mice, reaching its nadir ( $10 \%$ decrease) by day 5 p.i. In contrast, antibody-treated infected mice continued to lose weight through day 5 ( $4 \%$ total decrease) and then rapidly recovered (Fig. 3b). Virus titers were high in the lungs on days 2-7 p.i., peaking on day 5 (Fig. 3a), and did not differ

(b)

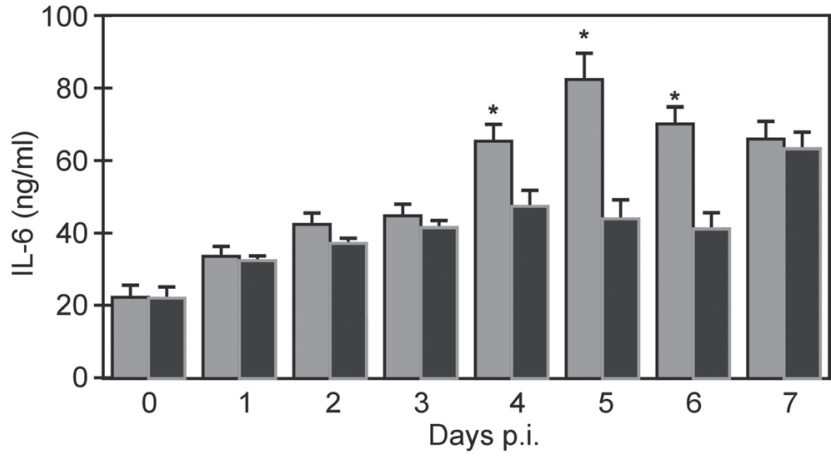

(d)

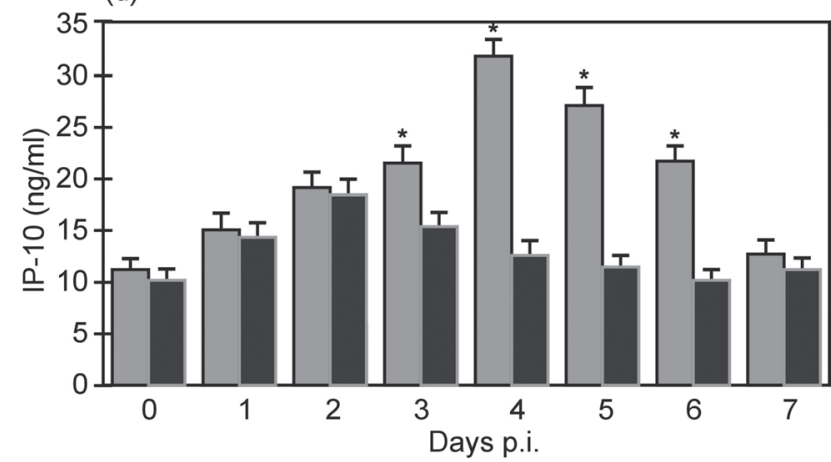

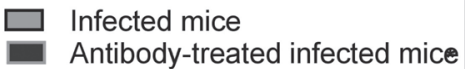

Fig. 2

HMGB1-specific antibody suppresses induction of inflammatory cytokines in virus-infected mouse lungs IL-1 $\beta$ (a), IL-6 (b), TNF- $\alpha$ (c), IP-10 (d), and RANTES (e). ${ }^{*} P<0.05$. 
between infected mice and antibody-treated infected mice. All infected mice died within 6 days p.i., whereas $20 \%(2 / 10)$ of antibody-treated infected mice survived beyond day 12 with no subsequent deaths (Fig. 3c). These results clearly show that HMGB1 is responsible for lethal viral effects following virus infection.

Virus-infected mice displayed an initial peribronchiolar patchy pneumonia on days $2-4$ p.i., with predominantly peribronchiolar lesions, progressing to fully developed bronchiolitis and bronchopneumonia by day 7 p.i. (Fig. 4). On day 5 p.i., severe interstitial pneumonia (Fig. 4 b and c) with edema, thickening and inflammatory cellular infiltration of the alveolar walls was found in infected mice, compared with milder symptoms in antibody-treated infected mice (Fig. 4d and e).

\section{Discussion}

We have demonstrated that IAV (H5N1) infection causes elevated expression of HMGB1 in the lungs of mice. Pulmonary HMGB1 mRNA did not increase until day 3 p.i., and its protein levels were significantly increased on day 4 p.i., when most mice had severe disease. In mouse models of endotoxemia and sepsis, HMGB1 is first detectable in the circulation $8 \mathrm{hr}$ after the onset of the lethal endotoxemia and sepsis, subsequently increasing to plateau levels from 16 to $32 \mathrm{hr}$ (Wang et al., 1999; Yang et al., 2004). This late appearance of circulating HMGB1 precedes and parallels the onset of animal lethality from endotoxemia or sepsis. The present results, showing that the HMGB1 levels peaked in the serum on day 5 p.i., when most mice had died, support the concept that the released HMGB1 contributes to IAV (H5N1)-induced mortality, as has been postulated elsewhere (Chu et al., 2003). Local or systemic production of HMGB1 is possible during influenza infections, since other viruses are known to induce HMGB1 release from infected cells (Chen et al., 2004, 2008). Visualization of HMGB1 expression in the lungs of IAV (H5N1)-infected mice by immunohistochemistry also showed that the bronchiolar epithelial cells, alveolar epithelial cells, and intercellular spaces contained large amounts of HMGB1 protein from days 3-5, consistent with the observed cellular HMGB1 expression in lung tissues. Furthermore, a difference in the profile of HMGB1 induced in the lungs by infectious versus inactivated IAV (H5N1) was also observed. HMGB1 production in the lungs requires viral replication, since HMGB1 expression in mice given inactivated virus was much lower than in infectious virus-infected mice. This is similar to what has been seen with $\mathrm{H} 5 \mathrm{~N} 1$ viruses in primary human type II pneumocytes, since inactivation of $\mathrm{H} 5 \mathrm{~N} 1$ virus by ultraviolet irradiation prior to the infection of the alveolar epithelial cells abolished the induction of IP-10, INF- $\beta$, RANTES, and IL-6 (Chan et al., 2005). The massive viral replication in the lungs may contribute to (a)

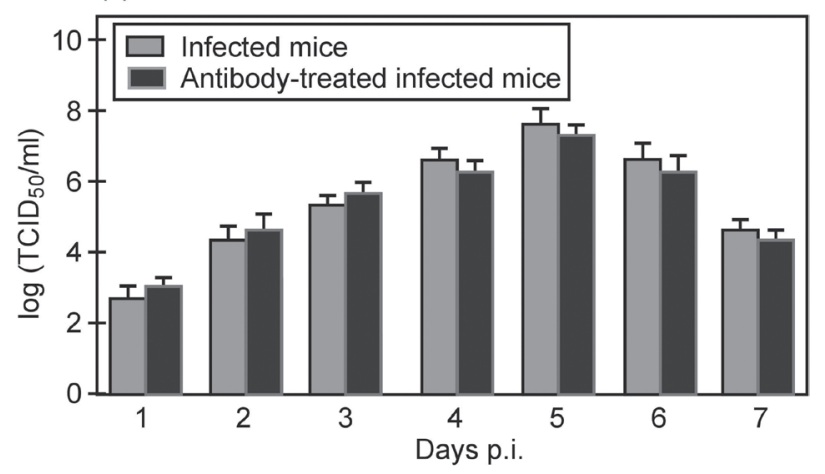

(b)

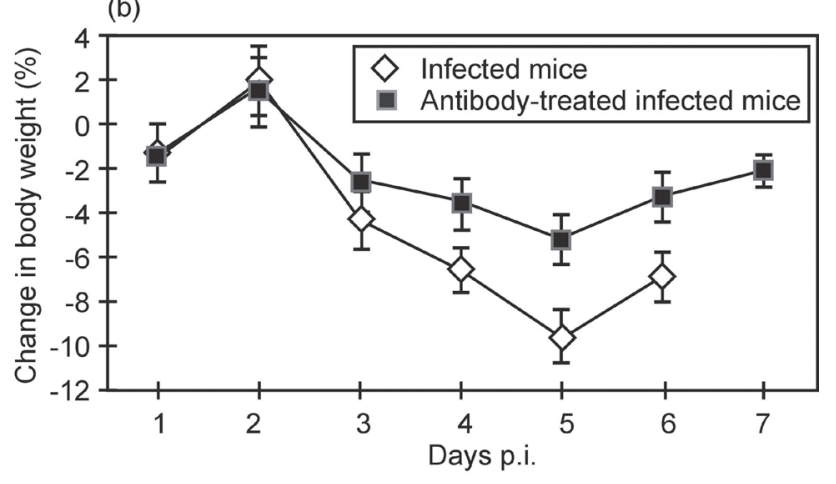

(c)

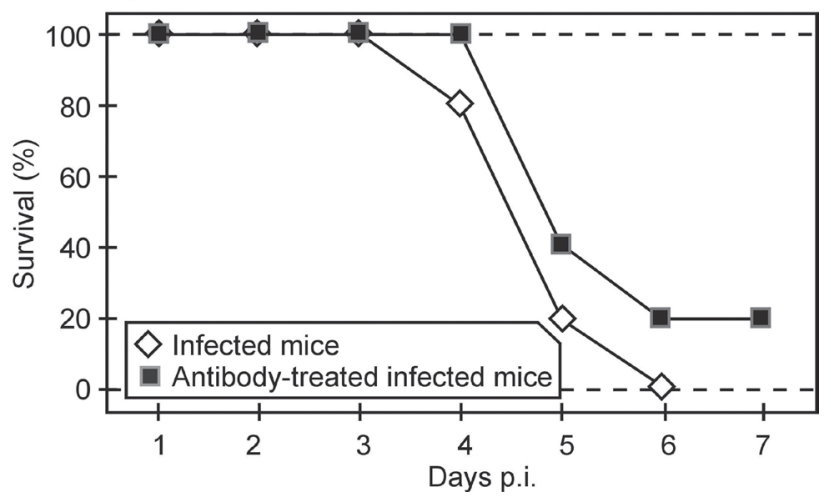

Fig. 3

HMGB1-specific antibody reduces morbidity and mortality in virusinfected mice

Infectious virus titer in the lungs (a), body weight (b) and survival time (c). ${ }^{*} P<0.05$

fatal IAV (H5N1) infection by eliciting an intense cytokine response. Given that HMGB1 functions as a late mediator cytokine and/or enhancer of proinflammatory activities of other cytokines, and that IAV (H5N1) induces HMGB1 release into the lungs, the role of HMGB1 required further investigation. IAV (H5N1)-infected mice were treated with 
Non-infected mice

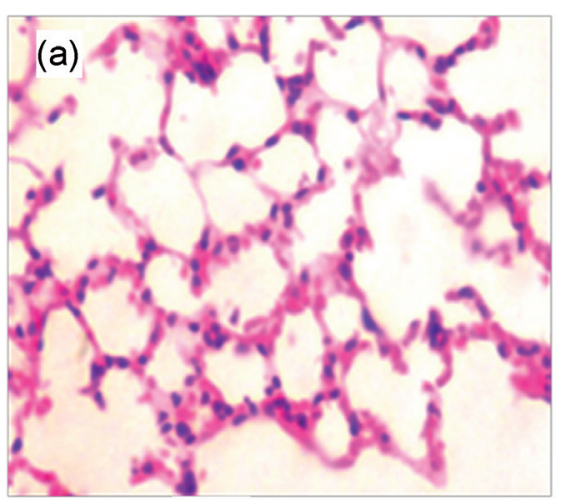

Infected mice
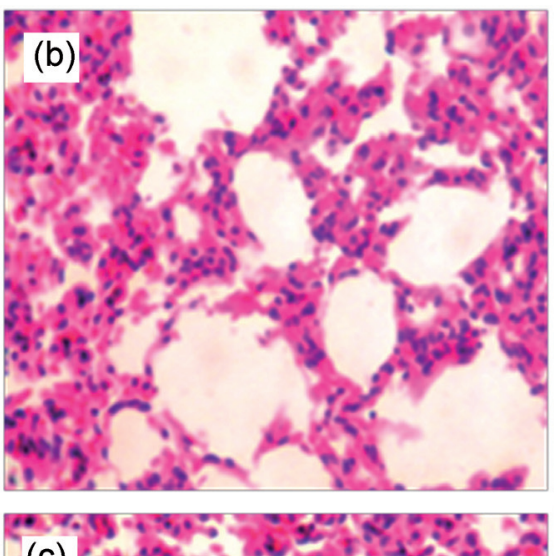

Antibody-treated-infected mice
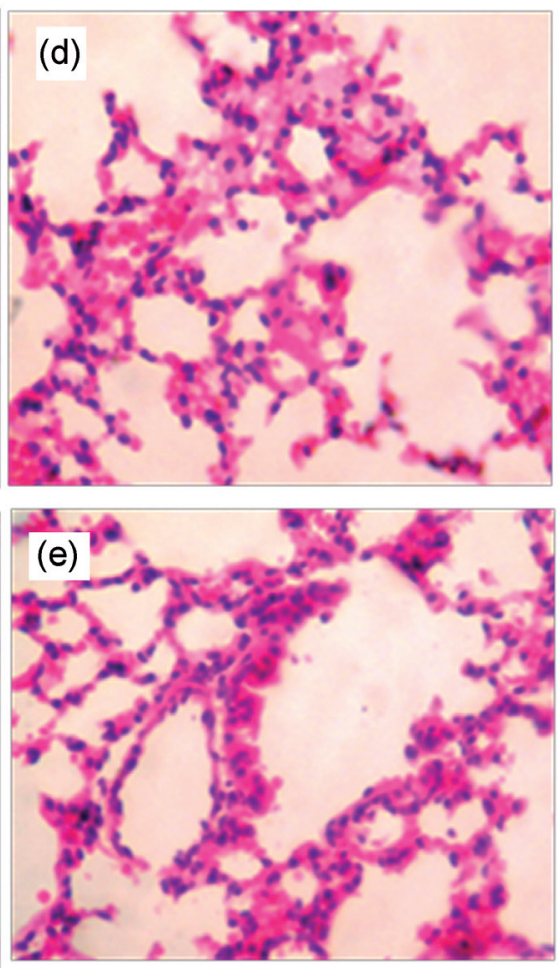

Fig. 4

HMGB1-specific antibody reduces inflammatory responses in virus-infected mouse lungs Non-infected mice (a), infected mice (b and c) and antibody-treated infected mice (d and e).

Table 1. Primers used in real-time PCR

\begin{tabular}{clcc}
\hline Gene & \multicolumn{1}{c}{ Primer (5'to 3') } & $\begin{array}{c}\text { PCR product } \\
\text { (bp) }\end{array}$ & Acc. No. \\
\hline HMGB1 & AAGAAGTGCTCAGAGAG & & \\
& GTGGAAG(F) & 235 & HBC085090 \\
& ATAAGCCAGGATGCTCG & & \\
& CC(R) & & \\
$\beta$-actin & TGACAGGATGCAGAAGG & & NM007393 \\
& AGA(F) & 131 & \\
& GCTGGAAGGTGGACAGT & & \\
& GAG(R) & & \\
\hline
\end{tabular}

HMGB1-specific antibody, which conferred significant protection against acute inflammation via inhibition of HMGB1 secretion (Kobasa et al., 2007). Following virus infection, mice treated with HMGB1-specific antibody had significantly reduced levels of IL-1 $\beta$, IL-6, TNF- $\alpha$, IP-10, and RANTES in the lungs, reduced loss of body weight and enhanced survival to more than 7 days $(P<0.05)$, but blocking of the HMGB1 activity had no significant effect on viral titers in the lungs during infection.
In summary, we have found that HMGB1 production in mouse lungs appears to correlate with death. This finding supports the hypothesis that HMGB1 is an important factor enhancing the inflammatory response in IAV (H5N1) infection, at least in the mouse model.

Acknowledgements. This work was supported by the grant No. 2011CB505002 from the Major State Basic Research Development Program of China and the grant No. 2010BAD04B01 from the Chinese National S\&T Plan Grant. The authors thank Prof. Yongming Yao for the advice and suggestions during this work.

Conflict of interest. The authors declare that they have no conflicts of interest.

\section{References}

Andersson U, Wang H, Palmblad K, Aveberger A, Bloom O (2000): High mobility group 1 protein (HMG-1) stimulates proinflammatory cytokine synthesis in human monocytes. J. Exp. Med. 192, 565-570. http://dx.doi.org/10.1084/ jem.192.4.565 
Barqasho B, Nowak P, Abdurahman S, Walther-Jallow L, Sönnerborg A (2010): Implications of the release of highmobility group box 1 protein from dying cells during human immunodeficiency virus type 1 infection in vitro. J. Gen. Virol. 91, 1800-1809. http://dx.doi.org/10.1099/ vir.0.016915-0

Bianchi ME, Manfredi AA (2007): High-mobility group box 1 (HMGB1) protein at the crossroads between innate and adaptive immunity. Immunol. Rev. 220, 35-46. http://dx.doi. org/10.1111/j.1600-065X.2007.00574.X

Chan MC, Cheung CY, Chui WH, Tsao SW, Nicholls JM, Chan YO, Chan RW, Long HT, Poon LL, Guan Y, Peiris JS (2005): Proinflammatory cytokines responses induced by influenza A (H5N1) viruses in primary human alveolar and bronchial epithelial cells. Resp. Res. 6, 135-142. http://dx.doi. org/10.1186/1465-9921-6-135

Chen G, Chen DZ, Li J, Czura CJ, Tracey KJ, Sama AE, Wang H (2004): Pathogenic role of HMGB1 in SARS? Med. Hypotheses 63, 691-695. http://dx.doi.org/10.1016/j.mehy.2004.01.037

Chu JJ, Ng LM (2003): The mechanism of cell death during West Nile virus infection is dependent on initial infectious dose. J. Gen. Virol. 84, 3305-3314. http://dx.doi.org/10.1099/ vir.0.19447-0

Dawson TC, Beck MA, Kuziel WA, Henderson F, Maeda N (2000): Contrasting effects of CCR5 and CCR2 deficiency in the pulmonary inflammatory response to influenza A virus. Am. J. Pathol. 156, 1951-1959. http://dx.doi.org/10.1016/ S0002-9440(10)65068-7

Deng R, Lu M, Korteweg C, Gao Z, McNutt MA, Ye J, Zhang T, Gu J (2008): Distinctly different expression of cytokines and chemokines in the lungs of two H5N1 avian influenza patients. J. Pathol. 216, 328-336. http://dx.doi.org/10.1002/ path. 2417

de Jong MD, Simmons CP, Thanh TT, Hien VM, Smith GJ, Chau TN, Hoang DM, Chau NV, Khanh TH, Dong VC, Qui PT, Cam BV, Ha do Q, Guan Y, Peiris JS, Chinh NT, Hien TT, Farrar J (2006): Fatal outcome of human influenza A (H5N1) is associated with high viral load and hypercytokinemia. Nat. Med. 12, 1203-1207. http://dx.doi.org/10.1038/nm1477

Grover A, Taylor J, Troudt J, Keyser A, Sommersted K (2008): Mycobacterial infection induces the secretion of high-mobility group box 1 protein. Cell Microbiol. 10, 1390-1404. http:// dx.doi.org/10.1111/j.1462-5822.2008.01135.X

Ito Y, Torii Y, Ohta R, Imai M, Hara S, Kawano Y, Matsubayashi T, Inui A, Yoshikawa T, Nishimura N, Ozaki T, Morishima T, Kimura H (2011): Increased levels of cytokines and highmobility group box 1 are associated with the development of severe pneumonia, but not acute encephalopathy, in 2009 H1N1 influenza-infected children. Cytokine 56,180-187. http://dx.doi.org/10.1016/j.cyto.2011.07.016

Jung JH, Park JH, Jee MH, Keum SJ, Cho MS, Yoon SK, Jang SK (2011): Hepatitis C Virus infection is blocked by HMGB1 released from virus- infected cells. J. Virol. 85, 9359-9368. http:// dx.doi.org/10.1128/JVI.00682-11

Kosai K, Seki M, Yanagihara K, Nakamura S, Kurihara S, Izumikawa K, Kakeya H, Yamamoto Y, Tashiro T, Kohno S (2008): Elevated levels of high mobility group box chromosomal protein-1 (HMGB-1) in sera from patients with severe bacterial pneumonia coinfected with influenza virus. Scand. J. Infect. Dis. 40, 338-342. http://dx.doi. org/10.1080/00365540701660486

Kobasa D, Jones SM, Shinya K, Kash JC, Copps J, Ebihara H, Hatta Y, Kim JH, Halfmann P, Hatta M, Feldmann F, Alimonti JB, Fernando L, Li Y, Katze MG, Feldmann H, Kawaoka Y (2007): Aberrant innate immune response in lethal infection of macaques with the 1918 influenza virus. Nature 445, 319-323. http://dx.doi.org/10.1038/nature05495

Messmer D, Yang H, Telusma G, Knoll F, Li J (2004): High mobility group box protein 1: an endogenous signal for dendritic cell maturation and Th1 polarization. J. Immunol. 173, 307-313.

Pandiri AR, Reed WM, Mays JK, Fadly AM (2007): Influence of strain, dose of virus, and age at inoculation on subgroup $\mathrm{J}$ avian leukosis virus persistence, antibody response, and oncogenicity in commercial meat-type chickens. Avian Dis. 51, 725-732. http://dx.doi.org/10.1637/0005-2086(2007)51[725:IOSDOV]2.0.CO;2

Schmitz N, Kurrer M, Bachmann MF, Kopf M (2005): Interleukin-1 is responsible for acute lung immunopathology but increases survival of respiratory influenza virus infection. J. Virol. 79, 6441-6448. http://dx.doi.org/10.1128/JVI.79.10.6441$\underline{6448.2005}$

Szretter KJ, Gangappa S, Lu X, Smith C, Shieh WJ, Zaki SR, Sambhara S, Tumpey TM, Katz JM (2007): Role of host cytokine responses in the pathogenesis of avian $\mathrm{H} 5 \mathrm{~N} 1$ influenza viruses in mice. J. Virol. 81, 2736-2744. http://dx.doi.org/10.1128/ JVI.02336-06

Van Zoelen MA, Van der Sluijs KF, Achouiti A, Florquin S, Braun-Pater JM, Yang H, Nawroth PP, Tracey KJ, Bierhaus A, Van der Poll $\mathrm{T}$ (2009): Receptor for advanced glycation end products is detrimental during influenza A virus pneumonia. Virology 391, 265-273 http://dx.doi.org/10.1016/j.virol.2009.05.032

Wang H, Bloom O, Zhang M, Vishnubhakat JM, Ombrellino M, Che J, Frazier A, Yang H, Ivanova S, Borovikova L, Manogue KR, Faist E, Abraham E, Andersson J, Andersson U, Molina PE, Abumrad NN, Sama A, Tracey KJ (1999): HMG-1 as a late mediator of endotoxin lethality in mice. Science 285 , 248-251. http://dx.doi.org/10.1126/science.285.5425.248

Yang H, Wang H, Czura C, Tracey K (2005): The cytokine activity of HMGB1. J. Leukoc. Biol. 78, 1-8. http://dx.doi.org/10.1189/ jlb.1104648

Yang H, Ochani M, Li JH, Qiang X, Tanovic M, Harris HE, Susarla SM, Ulloa L, Wang H, DiRaimo R, Czura CJ, Wang H, Roth J, Warren HS, Fink MP, Fenton MJ, Andersson U, Tracey KJ (2004): Reversing established sepsis with antagonists of endogenous high-mobility group box 1. PNAS 101, 296-301. http://dx.doi.org/10.1073/pnas.2434651100 